\title{
ENCONTRANDO PARAÍSO PERDIDO NUMA CONVERSAÇÃO PÓS-COLONIAL
}

RESUMO:

Ao usar o circuito pós-colonial de teoria e de prática textual de Edward Said, Gayatri Spivak e Homi Bhabha este ensaio introduz a possibilidade de uma des-leitura contrapontista de um texto de Milton: Paraíso Perdido poderá finalmente libertar-se de seu conteúdo colonial e liberar seu conteúdo pós-colonial.

PALAVRAS-CHAVE: John Milton, poesia, pós-colonialismo.

Em oposição ao início Dantesco, a descida ao inferno de Milton, no início de Paraíso Perdido, não é peripatética, nem gradual e muito menos suave. Começa-se a leitura do épico ${ }^{1}$ no meio do inferno do mesmo modo que no meio das coisas; e, apesar de tal início não ser sem precedente, um dos efeitos de se começar a ação épica a partir do inferno - e talvez num dos pontos mais cruciais de sua narrativa - é desconcertar os leitores de tal forma, que eles se sintam obrigados a suspender, pelo menos parcialmente, suas simpatias e seus julgamentos. No decorrer do texto, a teodicéia miltoniana não nos capacita necessariamente a resolver o problema do mal e do imperialismo e sim a dar um passo junto a Adão e Eva para fora do poema e para dentro de um mundo que se encontra num por-vir e em crise.

Essa crise inaugural que o poema solicita à tradição literária também solicita aos seus leitores uma devida atenção. 0 dentro e o fora do épico se tornam espaços escorregadios, superfícies textuais. Não há nenhum mecanismo ou origem anterior, seja estrutural ou autoral, que possa controlar os circuitos de significação entre épico e leitores, entre texto e recipiente ${ }^{2}$. Há tão somente um jogo "de" e "entre" superfícies textuais: ora a tradição literária clássica, ora a tradição literária renascentista européia, ora a tradição cristã, ora a tra(d)ição exegética * Doutor em Letras: Estudos Literários (Área de concentração: Literatura Comparada), 2001. 


\section{EM TESE}

Belo Horizonte, v. 6, p. I-253, ago. 2003

e cristã, ora a tra(d) ição de recepção deste texto. No lugar de querer dizer(meaningto-say), temos, nós leitores do épico, um querer jogar(meaning-as-play). Não é difícil ver como um texto na linha de Paraíso Perdido pode se tornar canônico em conseqüência de uma versão de leitura que normalmente circula como se fosse verdade ou mesmo, como se fosse toda a verdade. A falta de qualquer evidência inequívoca para decidir se Satã é um sujeito colonizador ou colonizado, ou se Adão é um sujeito colonizador ou colonizado, ou mesmo se Deus é um arquétipo do colonizador ou do criador, pode fazer Paraíso Perdido parecer um texto em curto circuito. Ou seja, um texto cujas diversas "tradições" são traições delas mesmas (não há nada debaixo da superficie do texto) e cuja ambivalência se torna cada vez mais aparente retrospectivamente (depois de leituras, re-leituras e des-leituras).

Mas antes que "Milton" (como metonímia de uma performance textual distintamente diferente) se tornasse sinônimo de tantos conceitos "canônicos" (puritano, cristão, europeu, colonizador) sua reputação como autor difícil (portanto elitista) e ambíguo já havia se estabelecido. "Milton", do centro do cânone inglês e mesmo no ápice de uma literatura mundial, já e sempre é considerado como que merecendo atenção crítica séria muito antes do termo pós-colonialismo se tornar popular (no meio da década de 90) no meio acadêmico. 0 termo pós-colonialismo, caso fosse aplicado ao nome "Milton", o seria apenas de maneira angular, na forma de destituição e repúdio. Na minha conversação pós-colonial com Paraíso Perdido, resgato o texto do paraíso de Milton como uma topografia esp(e)acial de performance textual de escrita e leitura e como uma geografia esp(e)acial de escrita e leitura de diferença; ou seja, resgato pequena parte daquilo que a crítica e a historiografia literária recalcaram de Paraíso Perdido e do nome "Milton".

A leitura "correta" do nome "Milton" ou do texto do paraíso é baseada numa repressão de leituras possíveis ou in-corretas, do mesmo modo que nossa "verdadeira" identidade depende do momento em que vemos uma imagem de nós mesmos refletida no espelho e que a re-conhecemos como alteridade, um outro de nós mesmos. Esse re-conhecimento então tem como base um des-conhecimento, do mesmo modo que uma leitura se baseia numa des-leitura. Uma vez que todo e qualquer ato de re-conhecimento e toda e qualquer ação de leitura se dão no simbólico, podemos inferir que todo reconhecimento é des-conhecimento e que toda leitura é uma des-leitura. Ou seja, todo querer dizer é um efeito estrutural des-controlado de um querer jogar com a palavra. 
A importância radical de tal constatação é que o paraíso de Milton, na minha desleitura, se torna uma pedra angular do termo pós-colonial: espaço de negociação, lugar de resgate do que foi recalcado, local de conflito e crise.

Em outras palavras, a diferença dentro da escrita do paraíso de Milton abre espaço para uma maior diferença entre escrita e crítica desse mesmo texto. É a partir dessa diferença consigo mesmo (da escrita do paraíso de Milton e da leitura de Paraíso Perdido, por exemplo), sua indecisão textual, que nós leitores podemos decidir por uma diferença e ler de que maneira ela ocorre no texto. Eu decidi por uma conversação e uma contracena pós-colonial para o paraíso de Milton. Ademais, essa indecisão textual do paraíso está mais do lado de heterogeneidade, alteridade e imaginação do que contra bom-senso, pensamento crítico ou racionalidade. Indecisão textual não está nem a favor de uma des-leitura radical e nem oposta a uma releitura conservadora. De novo, o que essa indecisão textual propicia é que decisões de leitura sejam feitas entre alternativas aparentemente opostas. A minha desleitura do paraíso de Milton não poderia nunca ambicionar resolver a indecisão desse texto ou destruir as outras decisões de leitura porque é impossivel esvaziar a inesgotável performatividade do querer jogar textual (meaning-as-play) que define, sem nunca chegar a definir totalmente, a natureza mesma do que é procurado, mas que sempre se coloca fora de alcance. A partir daí posso afirmar que Paraíso Perdido encontra uma cena pós-colonial, ou conversa num momento pós-colonial, sem com isso afirmar que Paraíso Perdido é pós-colonial em detrimento de renascentista, cristão, imperialista, etc.

Não há diferença real, em outras palavras, entre decidir se Satã é um colonizador ou se ele é um colonizado e, a partir da evidência de que o texto tem sua própria autoridade, decidir que isso faz parte de uma indecisão. Nesse caso, a indecisão textual funcionaria como tema, como substância dialética e temática de Paraíso Perdido cujo nível retórico seria lido como que contendo ou exprimindo. E isso não seria então diferente de decidir que o tema de Paraíso Perdido seria imperialismo nas suas variadas formas: ora porque Satã é um colonizador e então perpetra os males do imperialismo, ora porque Satã é um colonizado e então sofre dos males do imperialismo. Quaisquer escolhas que sejam feitas, devemos supor que elas foram feitas pelo texto mesmo: isso seria menos uma leitura de superfícies textuais e mais uma des-leitura entre elas. Como diz o narrador épico num dos inícios do 


\section{EM TESE}

Belo Horizonte, v. 6, p. I-253, ago. 2003

texto: sua "adventurous song" irá voar alto para além de um vôo médio "while it pursues / Things unattempted yet in prose or rhyme" (Milton, 1957: 233). 0 épico é uma música bem-aventurada que contará uma história/estória até então jamais relatada em prosa ou verso. De um lado, se Satã é lido como um colonizador, isso pode ser verificado em evidências textuais des-lidas a partir do nível retórico que suporta tal sentido. Do outro lado, se Satã é lido como um colonizado, isso também pode ser verificado em evidências textuais. Daí, o texto, ele mesmo, será lido como que em controle de seu conteúdo temático. Mas, e se o que o épico diz é que não há meio de dizer se Satã é um colonizador ou se ele é um colonizado, e que exatamente isso é o que significa uma diferença dentro do texto, então tal ordem de diferença não seria diferente da diferença entre "Satã é um colonizador" e "Satã é um colonizado", porque essa também é uma diferença que teria de ser entendida como que ocorrendo dentro do texto. A despeito de qualquer decisão, devemos reconhecer que a questão - é Satã um colonizador ou é ele um colonizado? - está contida no texto. De onde poderia tal questão vir? Se a resposta a tal questão é que não há resposta, então de onde poderia tudo isso vir senão de dentro do texto?

A ordem de diferença crítica a que estou me referindo é fundamentalmente distinta daquela que atribui ao texto uma autoridade e controle próprios. A diferença crítica aqui se refere e se define como os des-caminhos pelos quais o texto difere dele mesmo. Então não é autocontrole, mas auto-diferença que está em questão na minha des-leitura do paraíso de Milton. A estrutura de auto-diferença é comum a todo e qualquer texto e não somente ou particularmente às versões "difíceis" ou ambivalentes de uma dita alta literatura.

Numa leitura padrão, Paraíso Perdido é a história da queda de um terço dos anjos, da queda de Adão e Eva e da expulsão do casal do paraíso. E ao menos aí parece haver um consenso da crítica: o épico narra pelo menos duas quedas e algumas perdas. A partir dai vemos que esse texto de Milton atua de uma maneira definitiva na organização de sua obra: pode-se dizer que é o último testamento de um querer político e de um dizer espiritual provenientes de um autor de gênio. Para mim, então, há uma pergunta a ser feita quanto aos fins de Paraíso Perdido, já que pelo menos a um fim a história serve como que expressando uma vontade do autor ou sua intenção última. Quase no fim da carreira literária de Milton, Paraíso Perdido parece adquirir uma autoridade metalingüística para conceder uma certa finalidade 
e inteligibilidade a tudo que o precede. Esse sentido particular de finalidade é estritamente extra-textual: ele se encontra fora do texto.

Do mesmo modo, não há nenhum ponto definitivo dentro do texto no qual a história chega a um fim. Uma vez que o texto contém vários fins (como também contém vários inícios), a questão dos fins de Paraíso Perdido não pode ser relegada a um lugar subordinado fora do texto. Primeiro, a história termina com o exílio de Satã no inferno juntamente com seus pares. Mas essa queda não é suficiente e então o épico prossegue para mais uma queda e tem um outro fim na queda de Adão e Eva. Segundo, o épico não encerra, a história continua com as várias lições arcangélicas, advertências e ensinamentos. Seria esse um fim? Não. 0 texto caminha para uma seqüência em que leitores, anjo, Adão e Eva dão um passo para fora do paraíso e para fora do poema. Seria esse um fim?

Na minha des-leitura de Paraíso Perdido venho mostrando a dificuldade de decidir onde o texto de Milton inicia e onde esse texto finaliza. Mais genericamente, isso problematiza o próprio conceito de "texto" (esse em questão ou outros). 0 exato fim desse texto deve continuar numa interrogação porque nenhum dos quatro possivveis fins internos é finalmente conclusivo; mas esse texto também deve continuar numa interrogação em relação aos fins e finais de Milton, do autor. E especular sobre os vários possíveis fins desse texto é também especular sobre a herança crítica de seu autor; as diferenças críticas no decorrer dos anos mostram que não há um último e conclusivo fim em discussões e debates sobre Paraíso Perdido. Na minha des-leitura da crítica colonialista em Paraíso Perdido e na minha des-leitura (pós-)colonial de Paraíso Perdido venho mostrando que os conflitos e crises de leitura desse texto não estão indubitavelmente exteriores a ele: conflito e crise são parte fundamental na composição desse texto. As diferenças críticas no texto estão numa relação direta com as diferenças críticas sobre o texto. A articulação contraditória dos modos de significação dentro do texto corresponde às várias possibilidades de des-leituras do paraíso de Milton. Presumindo que a diferença textual de Paraíso Perdido e outros textos constrói para o primeiro uma identidade que é totalmente segura, muitos leitores também supõem que a questão da origem do mal e a questão da razão imperialista são respondidas dentro do texto. Como se o texto ele mesmo fosse a autoridade última, já e sempre tendo que ter a última palavra sobre qualquer julgamento. Paraíso Perdido não é uma explicação "OF MAN's first disobedience", 


\section{EM TESE}

Belo Horizonte, v. 6, p. I-253, ago. 2003

como também não pode ser uma justificação de "the ways of God to men" (Milton, 1957: 232-233). Paraíso Perdido é literatura; ele é texto, e em conseqüência disso não pode fixar, decidir conclusivamente, colonizar nenhum ponto. Dizer que não há um "vanishing-point" textual é também dizer que não há um "vanishing-point" para a literatura, ou seja, nenhum ponto no qual textualidade ou literatura venha a se fixar, parar definitivamente, decidir conclusivamente ou colonizar um sentido referencial. Isso também é dizer que literatura não tem uma identidade fundamental e, daí, que ela não pode se opor a alguma coisa fundamentalmente outra que ela mesma. Ao afirmar tudo isso, eu estou me referindo não somente à literatura, mas também aos espaços in-findos fora e dentro do texto (política, justiça, ética).

De volta a Paraíso Perdido e Milton, e ao segundo, mais especialmente, é muito difícil identificar qualquer "intenção autoral" ou "verdade" aparente no texto, uma vez que seu estilo, sua escrita e erudição encorajam tanto a especulação interpretativa quanto o conflito; em conseqüência disso, sua escrita é dissociada de sua "filosofia" ou "política" estrito senso e não pode ser lida como se fosse um meio transparente através do qual suas "intenções" seriam re-veladas. Defender Milton ao proclamar que os modernos Eliot e Pound ou que, de Leavis a Evans, a crítica literária des-leu Paraíso Perdido no sentido de equívoco, engano ou abuso, seria cometer outra des-leitura e negligenciar a premissa de que todo conhecimento pressupõe uma dose de re-conhecimento e des-conhecimento. Em outras palavras, minha des-leitura de Paraíso Perdido passa necessariamente por uma des-leitura da referida crítica literária sem com isso repudiar ou acusar de erro coisa alguma. É muito mais eficaz sabotar os textos que temos em mãos do que "querer dizer" de uma ética ou política pretendendo esconder ou retirar de cena o "querer jogar" da palavra e com a palavra. 0 "estilo" de Milton em Paraíso Perdido não pode ser negligenciado porque é de fundamental importância e o autor, poeta, tratadista, diplomata e outros tantos em "Milton" não podem ser defendidos porque: primeiro, eu não trato do autor, mas me fixo ao texto de Paraíso Perdido numa estratégia de des-leitura ou des-construção; segundo, eu não creio que o autor, Milton, deva ser acusado ou defendido porque sua intenção e verdade são formas bastardas no texto e do texto, menos transparentes e mais a-parentes; e terceiro, se já é um lugar-comum dizer que política estrito senso não se encontra no texto, uma des-leitura que leve em conta política, lato senso, no texto, já é singular. Para se montar uma defesa do autor, por outro lado, 
teríamos de acreditar que (efeitos da) Verdade ou (clamores de) verdade e retórica são separáveis em Milton. Em suma, se a filosofia e a política no texto em questão forem "reduzidas" à escrita, então não poderá haver (des-)leituras certas ou erradas de Paraíso Perdido ou de "Milton", mas apenas uma multiplicidade de leituras.

Não há dúvidas de que há várias e diferentes leituras do paraíso de Milton e de que não há nenhuma leitura "certa" acima de todas as outras. Mas não é suficiente dizer que há uma variedade e uma multiplicidade de leituras do paraíso de Milton, uma vez que há também a possibilidade de uma hierarquia de (des) leituras. Daí, não há somente diferenças horizontais (multiplicidade) como também diferenças verticais (hierarquia). 0 cancelamento de qualquer um desses eixos pode resultar numa certa perversão, numa banalização ou mesmo numa fria "desinfelicidade".

0 caso de (des-) leituras do paraíso de Milton, então, é uma singularidade: as diferenças extremadas de (des-)leitura do épico são um efeito da diferença, às vezes extrema, dentro do próprio épico, ou seja, sua escrita. Não podemos sugerir que há uma intenção autoral ou verdade pro-clamada inscrita nessa escrita, como também não podemos supor que esse texto esteja aberto a todo e qualquer jogo de sentido ou interpretação. Então, como o paraíso de Milton é (des-)lido não pode ser dissociado da escrita do paraíso, ou do quê Milton escreveu, mas também não pode ser reduzido a tão somente isso. Posso dizer que, ao des-ler o paraíso de Milton, eu sou obrigado a emprestar a minha atenção à sua escrita no sentido mais literal possível - às palavras nas linhas do épico, como estão escritas -, mas não para encontrar "um" "sentido" unitário ou coerente atrás/sob cada palavra. Em vez disso, noto como alguns interesses "fora" do paraíso de Milton podem se atar (atracar com?) a certos mecanismos retóricos no mesmo texto, tentando levar o último a se prostrar perante esses mesmos interesses. Parece-me que o objetivo de todos esses interesses é determinar o sentido de Paraíso Perdido de Milton - ter poder sobre o texto. E ainda assim, posso dizer que, dada a afirmação da vontade de poder e desejo de (des)conhecimento nesse texto de Milton, esses interesses podem dificilmente ser vistos como "externos" ao texto. A questão não é, no entanto, que (des-) leituras "interessadas" estão fora do texto ou que uma certa "verdade desinteressada" está dentro do texto, mas antes que Paraíso Perdido joga com o problema das relações dentro e fora do texto de modo que a diferença entre o que Milton escreveu, o que Milton quis dizer e o que nós, seus leitores, (des-)lemos continua uma grande in- 


\section{EM TESE}

Belo Horizonte, v. 6, p. I-253, ago. 2003

decisão (de poder). Minha des-leitura do paraíso de Milton des-conhece, tanto quanto possível, os imperialismos de leitura de uma obra desse autor, re-conhece não só as dificuldades, mas também as diferenças que podem vir a se passar como desculpas de colonização desse texto e conhece que a diferença do paraíso de Milton com ele mesmo não é absolutamente interna ou externa, como também não é horizontal (associativa) ou vertical (seletiva), mas está, antes de tudo, em conflito e crise permanentes. E crise, e conflito, e luta de leituras e des-leituras é uma seqüência in-fame de fundamental ligação entre Paraíso Perdido e estudos (momento, espaço, teoria e prática) pós-coloniais. Des-conheçamos assim um jardim para lá de ocupado e e(n)dên(m)ico da palavra, "milton" e seu "paraíso".

NOTAS:

1. Tomo a liberdade, por meio de uma derivação imprópria, de utilizar "épico" como substantivo masculino nas seguintes acepções: 1. grande composição em que o poeta canta uma ação heróica e 2. autor de uma epopéia.

2. Utilizo-me de "recipiente", em vez de "receptor", para me afastar das premissas e das pressuposições decorrentes de teorias de recepção de texto. "Recipiente", neste caso também uma derivação imprópria, seria um substantivo mascul ino com o seguinte significado genérico: pessoa, máquina ou coisa que recebe (os produtos de qualquer operação).

ABSTRACT :

By using Edward Said's, Gayatri Spivak's, and Homi Bhabha's circuit of post-colonial theory and practice, this paper introduces the possibility of a counterpointal (mis) reading of Milton's text: Paradise Lost may at last free its (post-) colonial (dis) content.

KEY WORDS: John Milton, poetry, post-colonialism.

REFERÊNCIA BIBLIOGRÁFICA

MILTON, John. John Milton: Complete Poems and Major Prose. HUGHES, Merritt Y. (Ed.). New York: [s.n.], 1957. 